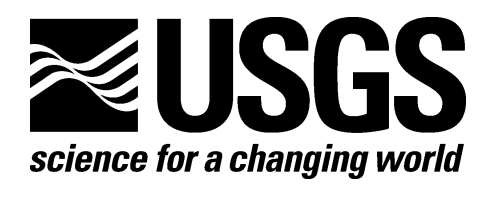

\title{
MAPPING LAND USE/LAND COVER IN THE Ambos Nogales Study AREA
}

By Laura M. Norman and Cynthia S.A. Wallace

Open File Report 2008-1378

U.S. Department of the Interior

U.S. Geological Survey 


\section{U.S. Department of the Interior DIRK KEMPTHORNE, Secretary}

\section{U.S. Geological Survey}

Mark D. Myers, Director

U.S. Geological Survey, Reston, Virginia 2008

For product and ordering information:

World Wide Web: http://www.usgs.gov/pubprod

Telephone: 1-888-ASK-USGS

For more information on the USGS - the Federal source for science about the Earth, its natural and living resources, natural hazards, and the environment: World Wide Web: http://www.usgs.gov

Telephone: 1-888-ASK-USGS

Suggested citation:

Norman, L.M., and Wallace, C.S.A., 2008, Mapping land use/land cover in the Ambos Nogales study area: U.S. Geological Survey Open-File Report 2008-1378, 42 p.

Any use of trade, product, or firm names is for descriptive purposes only and does not imply endorsement by the U.S. Government.

Although this report is in the public domain, permission must be secured from the individual copyright owners to reproduce any copyrighted material contained within this report. 


\section{CONTENTS}

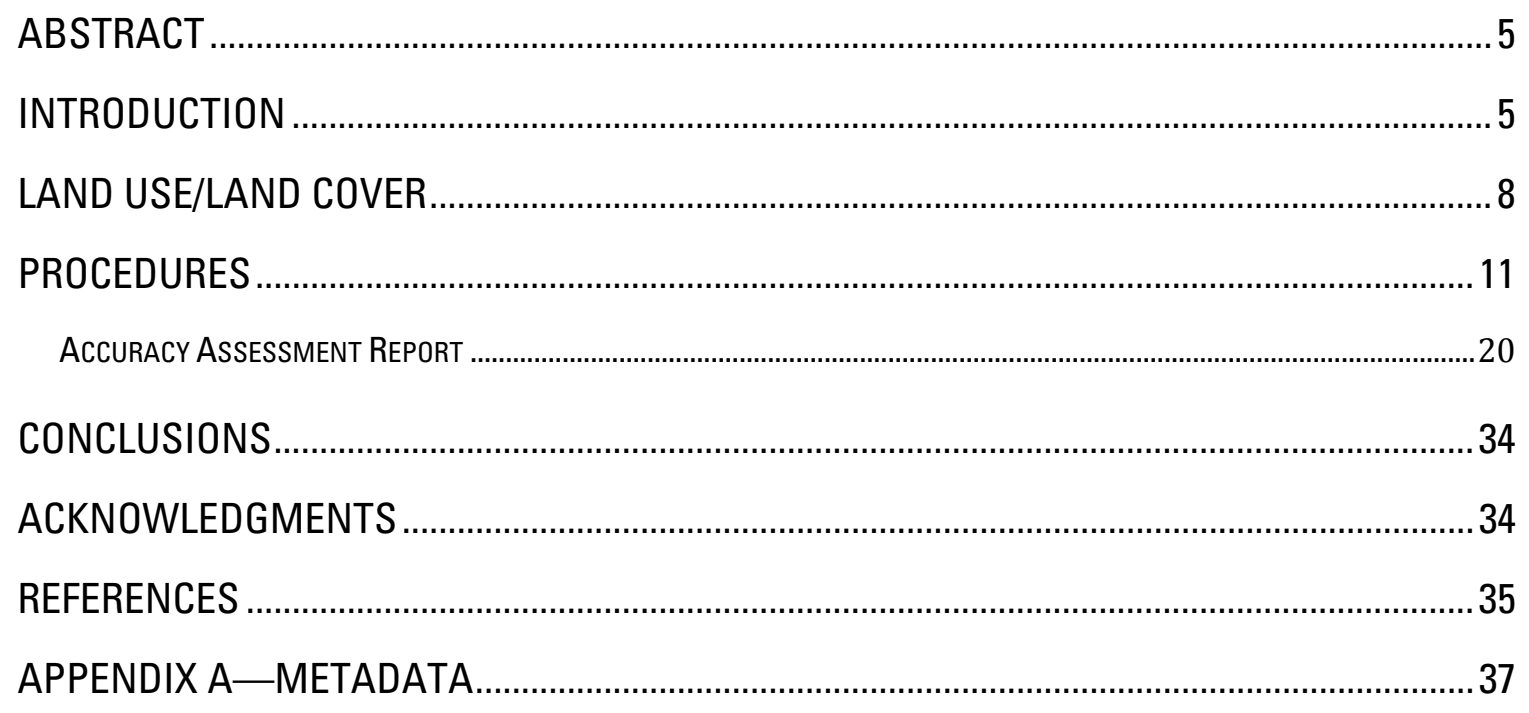

\section{List of Figures}

Figure 1. Location map of the Ambos Nogales watershed along the International border of Arizona, United States, and Sonora, Mexico.

Figure 2: National Land Cover Data (NLCD) data for Nogales, Arizona, in the Ambos Nogales watershed.

Figure 3. Binational Land-cover dataset for Ambos Nogales. Arizona, United States, and Sonora, Mexico.

Figure 4. North American Landscape Characterization (NALC) image over Ambos Nogales, Arizona, United States, and Sonora, Mexico, acquired on October 7, 1992, by using Landsat Multi-Spectral Scanner data.

Figure 5. ERDAS IMAGINE 9.1 AOI tool editor and example of samples in Nogales, Arizona.

Figure 6. Signature Editor in ERDAS IMAGINE 9.1 and 8 signatures..........................................14

Figure 7. National Land Cover Data Maps. A., Ambos Nogales watershed land cover (60-m resolution), Arizona, United States, and Sonora, Mexico; B., Ambos Nogales watershed land cover (30-m resolution), Nogales, Arizona. 
Figure 8: DOQQ of area south of the U.S.-Mexico border.

Figure 9. Residential area in Nogales, Sonora, that was classified as Bare Rock/Sand/Clay.

Figure 10: Picture of colonias at the U.S.-Mexico border in Ambos Nogales showing lack of pavement on roads in this watershed. 20

Figure 11. Screengrab of ERDAS IMAGINE Signature Editor with 6 classes. .25

Figure 12. Image of property at the U.S.-Mexico border between Marisposa Rd. and I-19 in Nogales, Arizona.

Figure 13. Photo of development land taken near Highway 82 in Nogales, Arizona...... .30

Figure 14. MRLC look-up table available in AGWA2.

Figure 15. New “Class" attribute assigned to binational map.

Figure 16. Final attribute table for the raster binational land-cover input of Ambos Nogales, Arizona, United States, and Sonora, Mexico.

Figure 17. Final binational land-cover map of Ambos Nogales, Arizona, United States, and Sonora, Mexico, for input to AGWA2.

\section{List of Tables}

Table 1. Error Matrix

Table 2. Accuracy Totals.

Table 3. Conditional Kappa for each Category.

Table 4. Error Matrix .26

Table 5. Accuracy Totals. .27

Table 6. Errors of omission, commission, and percent correct. 


\title{
Mapping Land Use/Land Cover in the Ambos Nogales Study Area
}

By Laura M. Norman and Cynthia S.A. Wallace

\begin{abstract}
The Ambos Nogales watershed, which surrounds the twin cities of Nogales, Arizona, United States and Nogales, Sonora, Mexico, has a history of problems related to flooding. This paper describes the process of creating a high-resolution, binational land-cover dataset to be used in modeling the Ambos Nogales watershed. The Automated Geospatial Watershed Assessment tool will be used to model the Ambos Nogales watershed to identify focal points for planning efforts and to anticipate ramifications of implementing detention reservoirs at certain watershed planes.
\end{abstract}

\section{Introduction}

Watersheds located along the Arizona-Sonora border of the United States and Mexico are especially susceptible to flooding and erosion during the summer monsoon season. Soils in this semi arid region typically have high caliche content (hard deposit of calcium carbonate), making them relatively impermeable and leading to enhanced runoff and increased risk of flash floods and debris flows. Homes, livelihoods, and even lives are threatened by these hazards. In Ambos Nogales (fig. 1), landslides and erosion of roads and hillslopes threaten surface water quality, contaminating streams with sediments and included toxins. Sewers in Nogales, Sonora, are not equipped to handle some loads and have caused fecal contamination of ground-water supplies in times of flood. In the face of climate change and imminent urban growth, scientists can offer prediction scenarios of what might happen during extreme events. 
In order to determine the effects of flooding scenarios and urban growth for future planning, a model will be applied. The Kinematic Runoff and Erosion (KINEROS2) Model was developed by the U.S. Department of Agriculture-Agricultural Research Service (USDA-ARS) to simulate runoff, infiltration, interception, and erosion based on precipitation events (Woolhiser and others, 1970). This model can be applied within a GIS to represent spatial distribution within a watershed using the Automated Geospatial Watershed Assessment (AGWA2) Tool (Miller and others, 2002; Semmens and others, 2008). Four inputs are required to run the model (1) watershed elements (for example, topography and slope), (2) soil types, (3) precipitation information, and (4) land-cover data. Land-cover data is not readily available at a high enough resolution to simulate processes within this small watershed. 


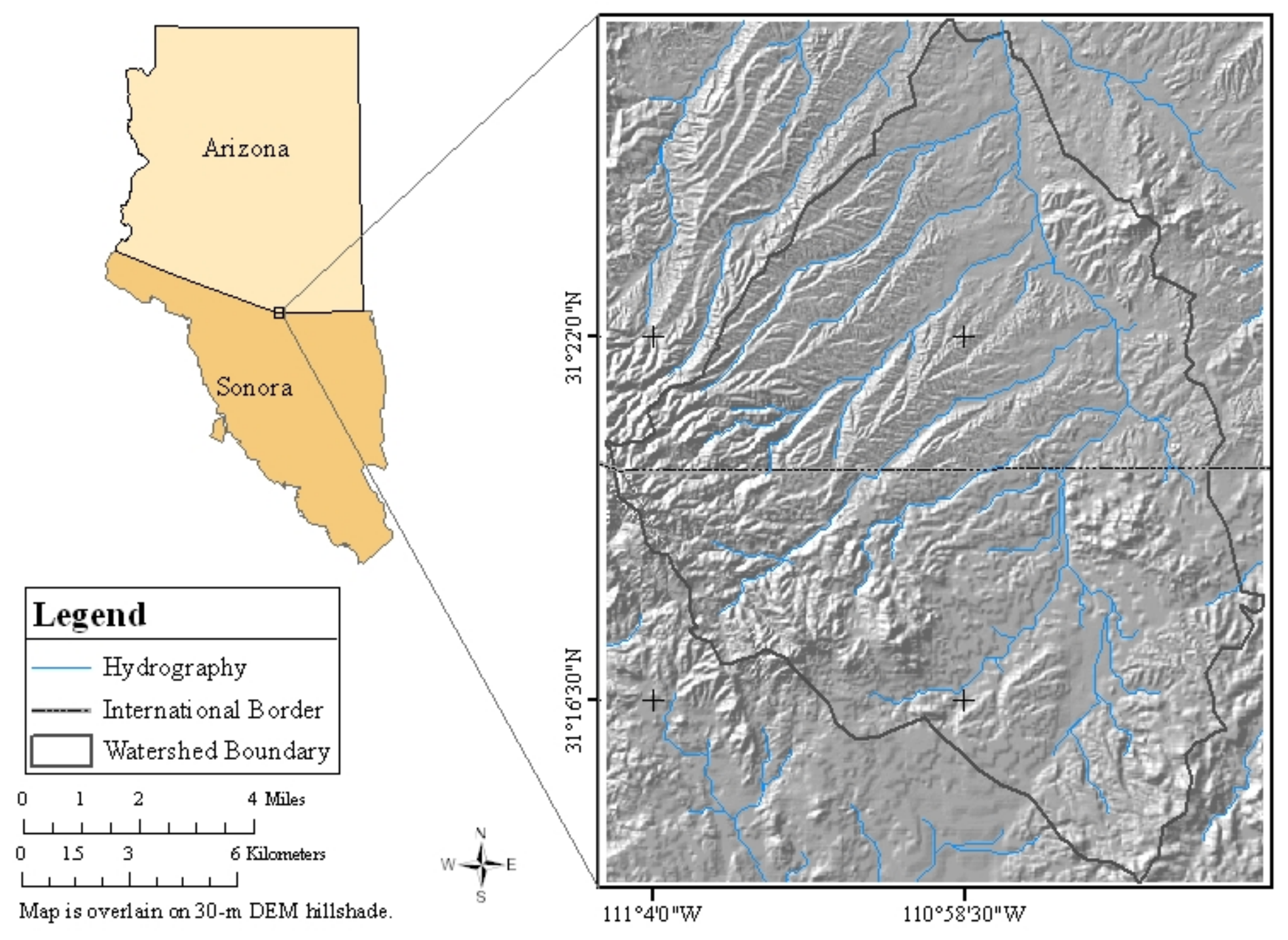

Figure 1. Location map of the Ambos Nogales watershed along the International border of Arizona, United States, and Sonora, Mexico. 


\section{Land Use/Land Cover}

An integer grid dataset representing the distribution of land-cover classes across the study area is required for input to AGWA2. Several datasets are supported by AGWA2 natively, including the North American Landscape Characterization (NALC; Lunetta and Sturdevant, 1993), Multi-Resolution Land Cover Characterization (MRLC; Loveland and Shaw, 1996), and Gap Analysis Program (GAP; Gaydos, 1996) land covers. The National Land Cover Data (NLCD; Vogelmann and others, 2001) is a dataset that maps the conterminous United States into 21-classes of land cover. The spatial resolution is 30-meters derived from Landsat Thematic Mapper (TM) satellite imagery. We acquired NLCD data for Nogales, Arizona (fig. 2). 


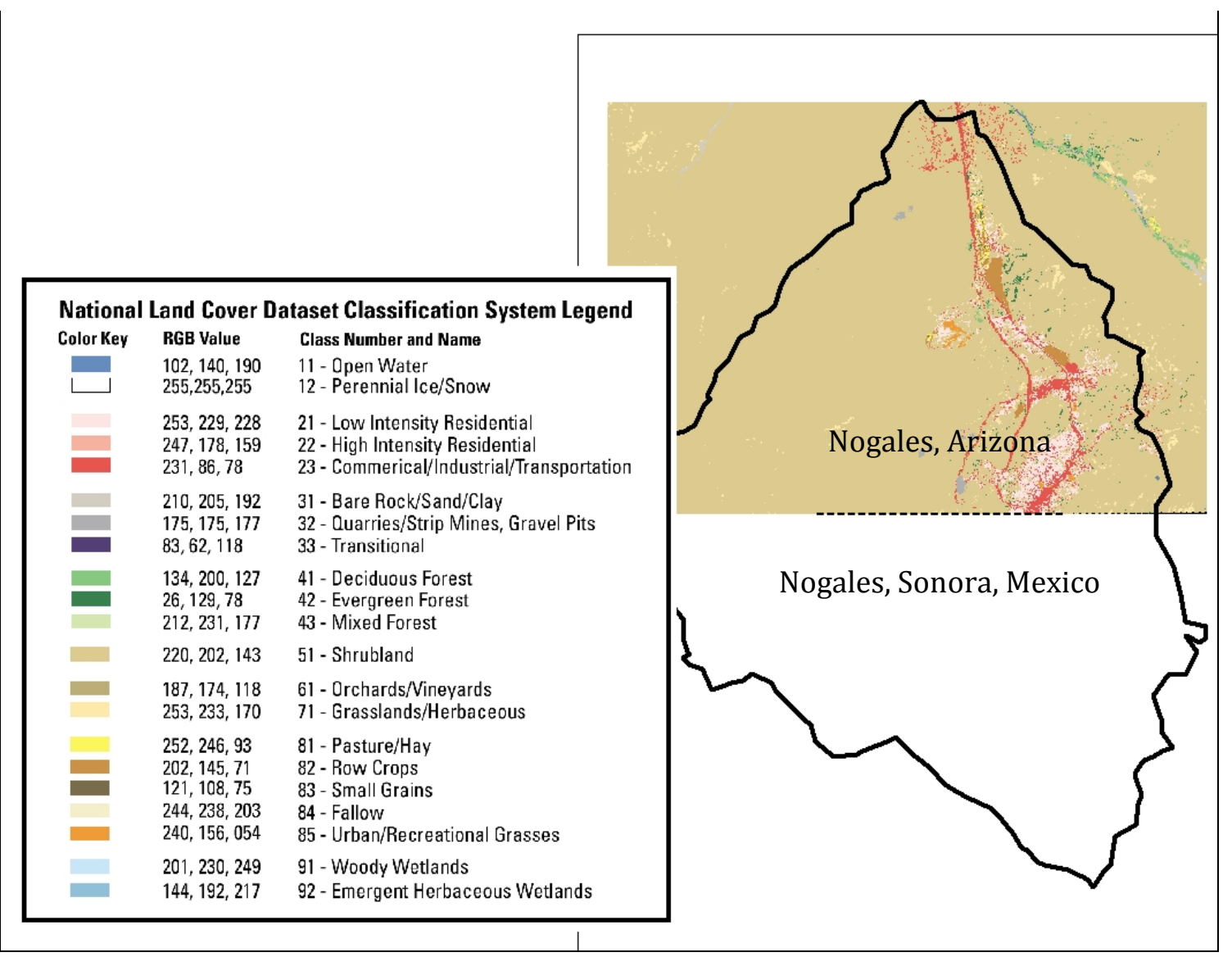

Figure 2: National Land Cover Data (NLCD) data for Nogales, Arizona, in the Ambos Nogales watershed.

The U.S. Geological Survey’s (USGS) Border Environmental Health Initiative combined Mexico’s Instituto Nacional de Estadística, Geografía, e Informática (INEGI) 1:250,000 Uso de Suelo (Land Use) dataset (1993) with NLCD (1992) to make a border-wide Binational Land Cover dataset (http://borderhealth.cr.usgs.gov/index.html, last accessed December 21, 2008). Eight land-cover classes were mapped to a generalized, modified Anderson Level I (Anderson and others, 1976) binational classification system to which both countries’ Land Use/Land Cover (LULC) data could be reclassified (Parcher and others, 2006; Wilson, 2006; fig. 3). 


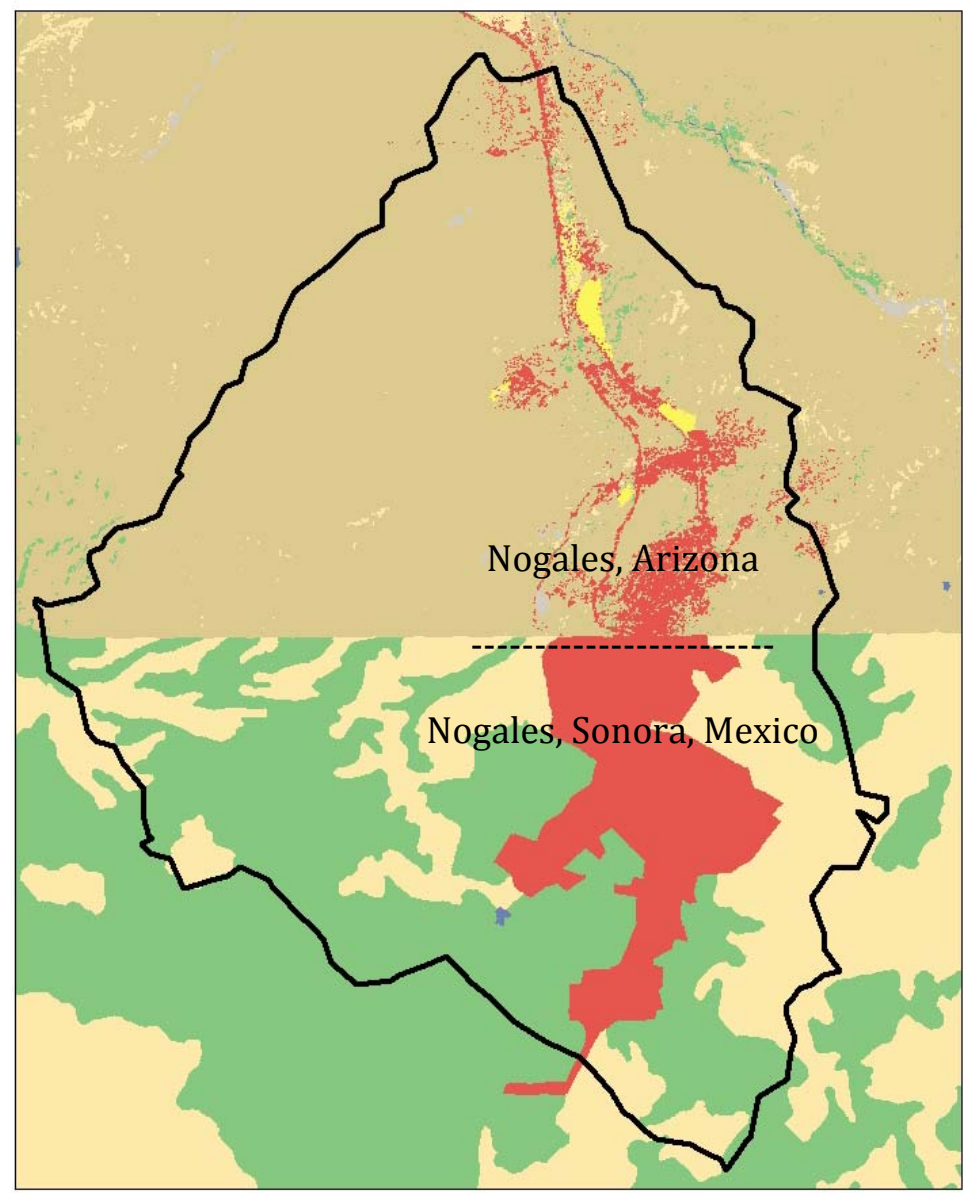

\begin{tabular}{|l|}
\hline \multicolumn{1}{|c|}{ EXPLANATION } \\
Developed \\
Agriculture \\
Forest \\
Shrubland \\
Water \\
Barren \\
Grassland/Pasture \\
Wetland/Halophillic \\
vegetation \\
\hline
\end{tabular}

Figure 3. Binational Land-cover dataset for Ambos Nogales. Arizona, United States, and Sonora, Mexico.

The binational data has been reclassified and was derived entirely from Landsat interpretations; however, the original datasets were captured through different processes. The Mexican data were digitized polygons of land use, while the NALC data were classified using automated techniques resulting in a raster dataset. The LULC data represented by the polygons tend to present a more homogeneous picture of the landscape; the raster data represent more heterogeneity (Parcher and others 2006, Wilson 2006). While the binational dataset does provide a good qualitative representation of regional patterns in LULC, a more heterogeneous dataset is desirable to support the complexity needed for calculating hydrological parameters of a small watershed. 


\section{Procedures}

The NALC data are Landsat Multi-Spectral Scanner (MSS) time-series triplicates that were acquired in 1973, 1986, and 1991 (+/- one year). Pixel size for all images is 60 meters. NALC triplicates were acquired for Path 36, Row 38. The dataset from October 7, 1992 were used for this processing (fig. 4).

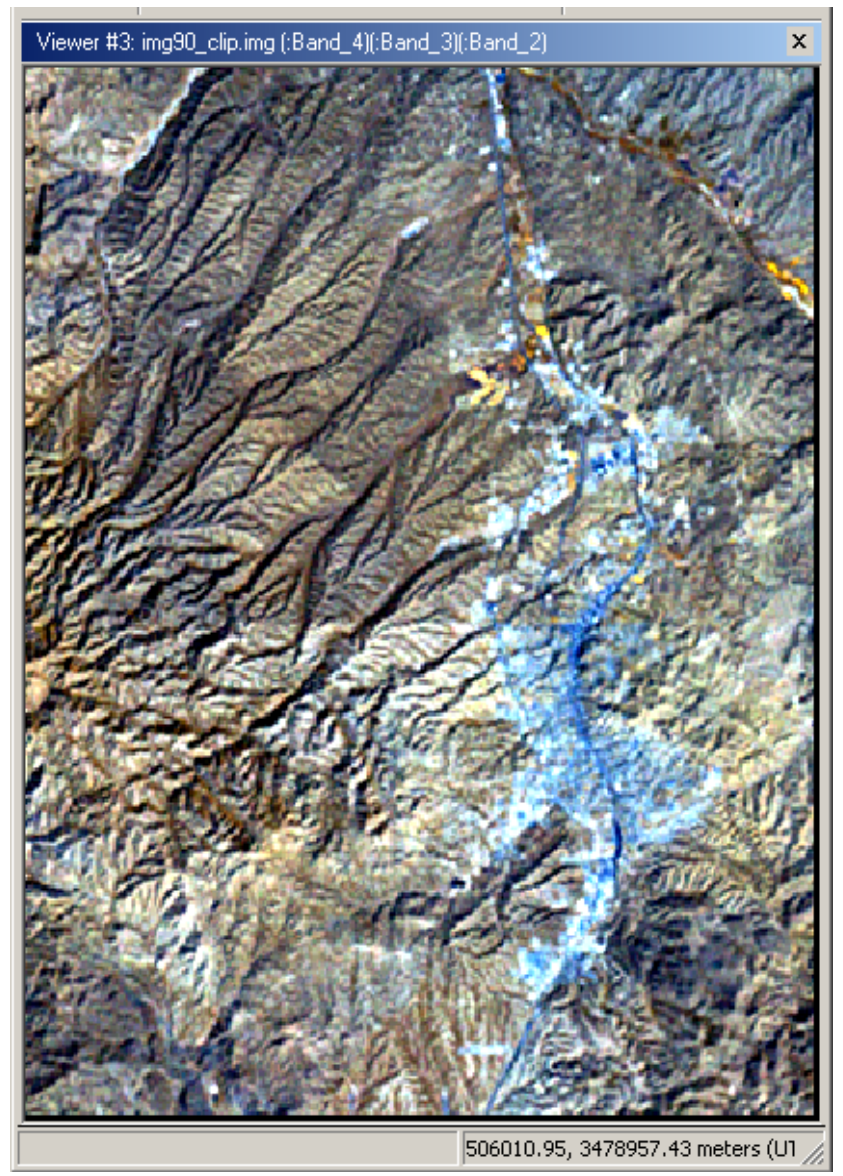

Figure 4. North American Landscape Characterization (NALC) image over Ambos Nogales,

Arizona, United States, and Sonora, Mexico, acquired on October 7, 1992, by using Landsat MultiSpectral Scanner data.

Using ERDAS IMAGINE 9.1 software, we extracted forty-five samples of land cover, based on dead-reckoning, and compared them with the classification scheme available from the NLCD using the Area of Interest (AOI) tool editor (fig. 5), to represent the full range of land 
cover in the watershed. The AOI feature allows the user to draw polygons around distinct features and relate the signatures back to a known reference. 




Figure 5. ERDAS IMAGINE 9.1 AOI tool editor and example of samples in Nogales, Arizona. 
From the 45 samples identified, we merged the samples into 8 signatures that correlate with the

NLCD classes occurring in the Ambos Nogales watershed: (1) Deciduous Forest, (2) Bare

Rock/Sand/Clay, (3) Quarries/Strip Mines/Gravel Pit, (4) Grassland/Herbaceous, (5) Urban/Recreational Grasses, (6) Shrubland, (7) Low Intensity Residential, and (8) Commercial/Industrial/Transport (fig. 6).

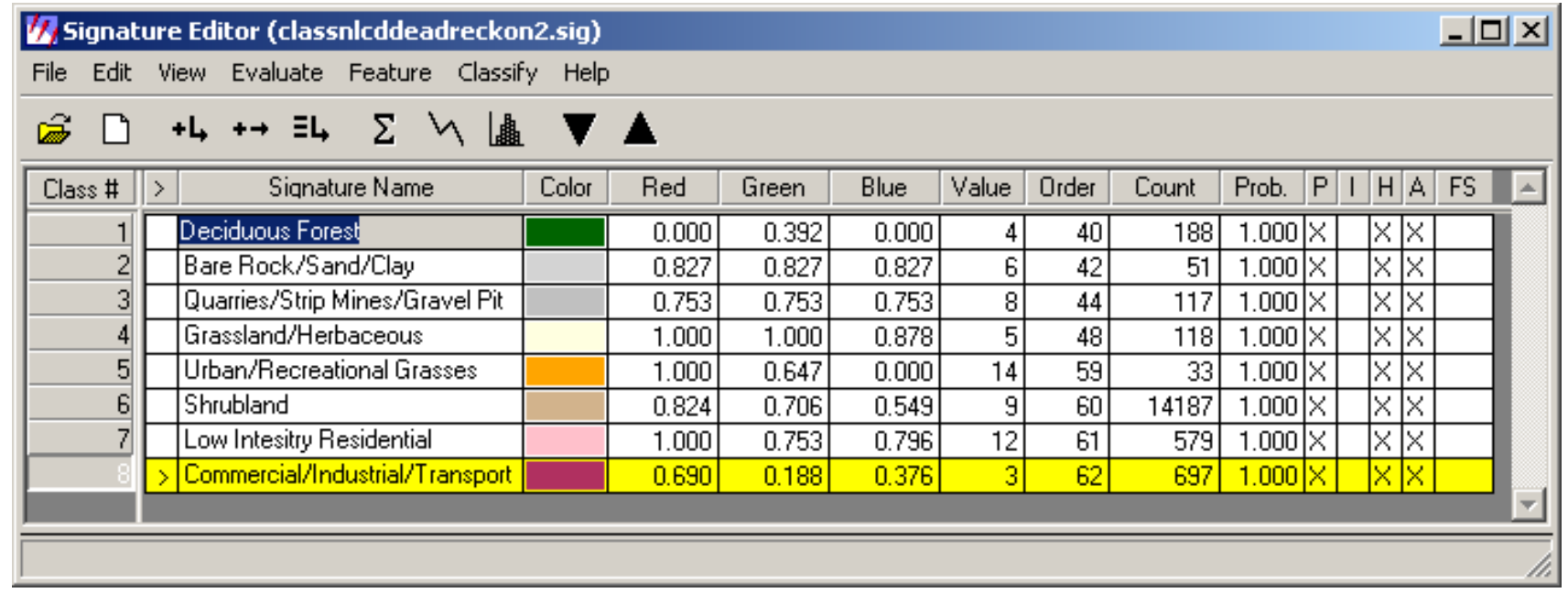

Figure 6. Signature Editor in ERDAS IMAGINE 9.1 and 8 signatures.

We applied a supervised classification, using these 8 signatures and the minimum distance rule, to map each pixel in the MSS scene into one of the 8 classes to create a new map of land cover in the watershed (fig. 7). 


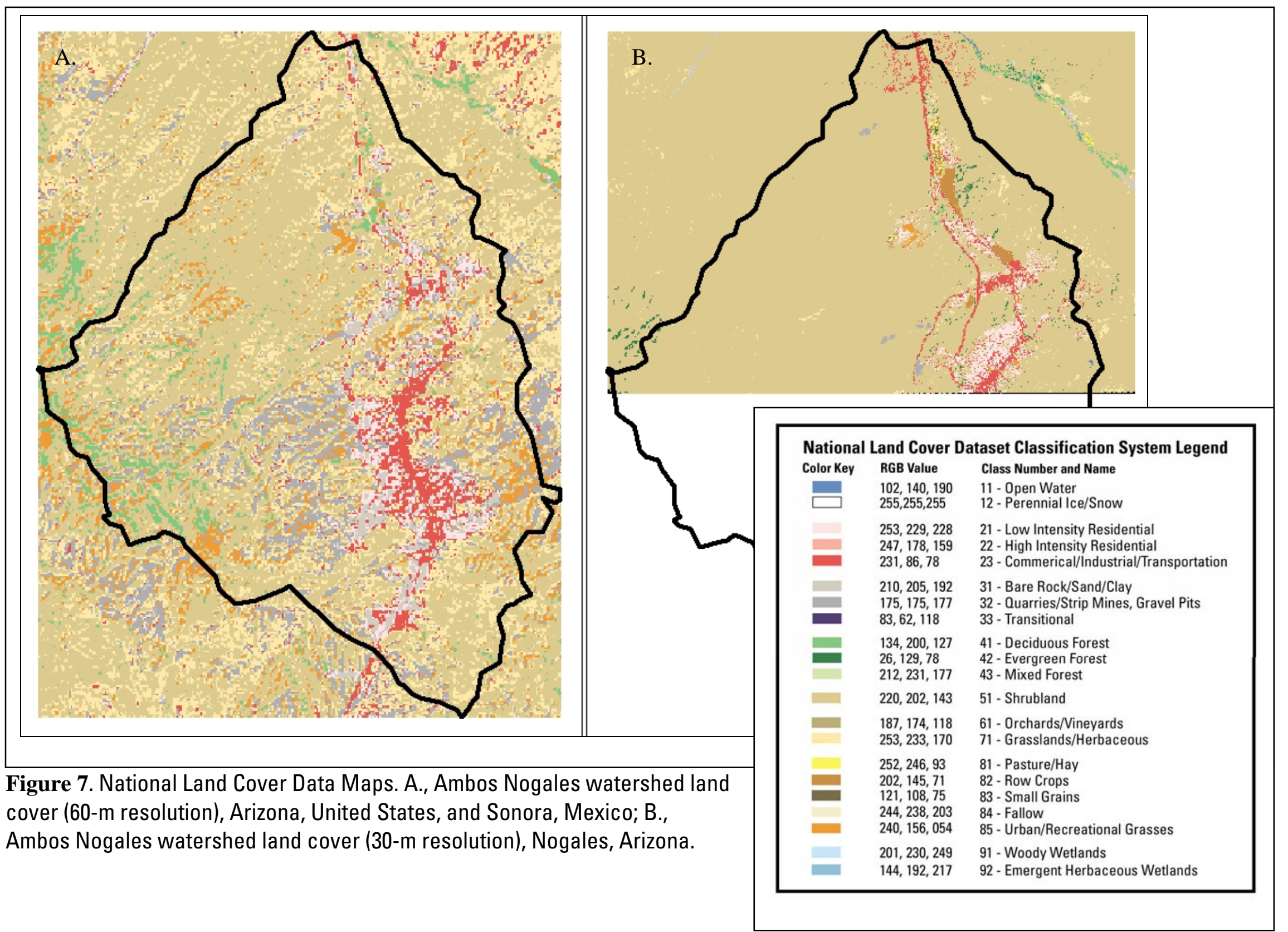


To check the accuracy of the newly created binational land-cover map, we developed a stratified sampling regime by assigning random points (reference pixels) to the classified image. ERDAS IMAGINE 9.1 uses a square window to select the reference pixels and the number of points is stratified to the distribution of thematic layer classes. Congalton (2001) and Congalton and Green (1999) suggest using a minimum sample size of 50 per class.

This creates a CellArray that lists two sets of class values for the randomly selected points from the classified map file. One set of class values is the land-cover class from the new map, and the other set of class values (reference values) is determined from higher resolution images by the analyst.

For each randomly selected point, we manually compared the classification on the NCLD map of Nogales, Arizona, the 1995-1996 Digital Orthophoto Quarter Quadrangles (DOQQs) of Nogales, Arizona, from the USGS, and of Nogales, Sonora, from INEGI to identify the reference points. These orthophotos are taken at a 1-m resolution and can be zoomed in on to determine actual composition of land use. Some points were not accurately classified.

A large area south of the International border was classified as Quarries/mines, but according to the DOQQ, reference point \#98 is located in areas of widely dispersed mesquite or creosote surrounded by bare soil, a land cover reclassified as Shrubland and Bare rock/Sand/Clay (fig. 8). 


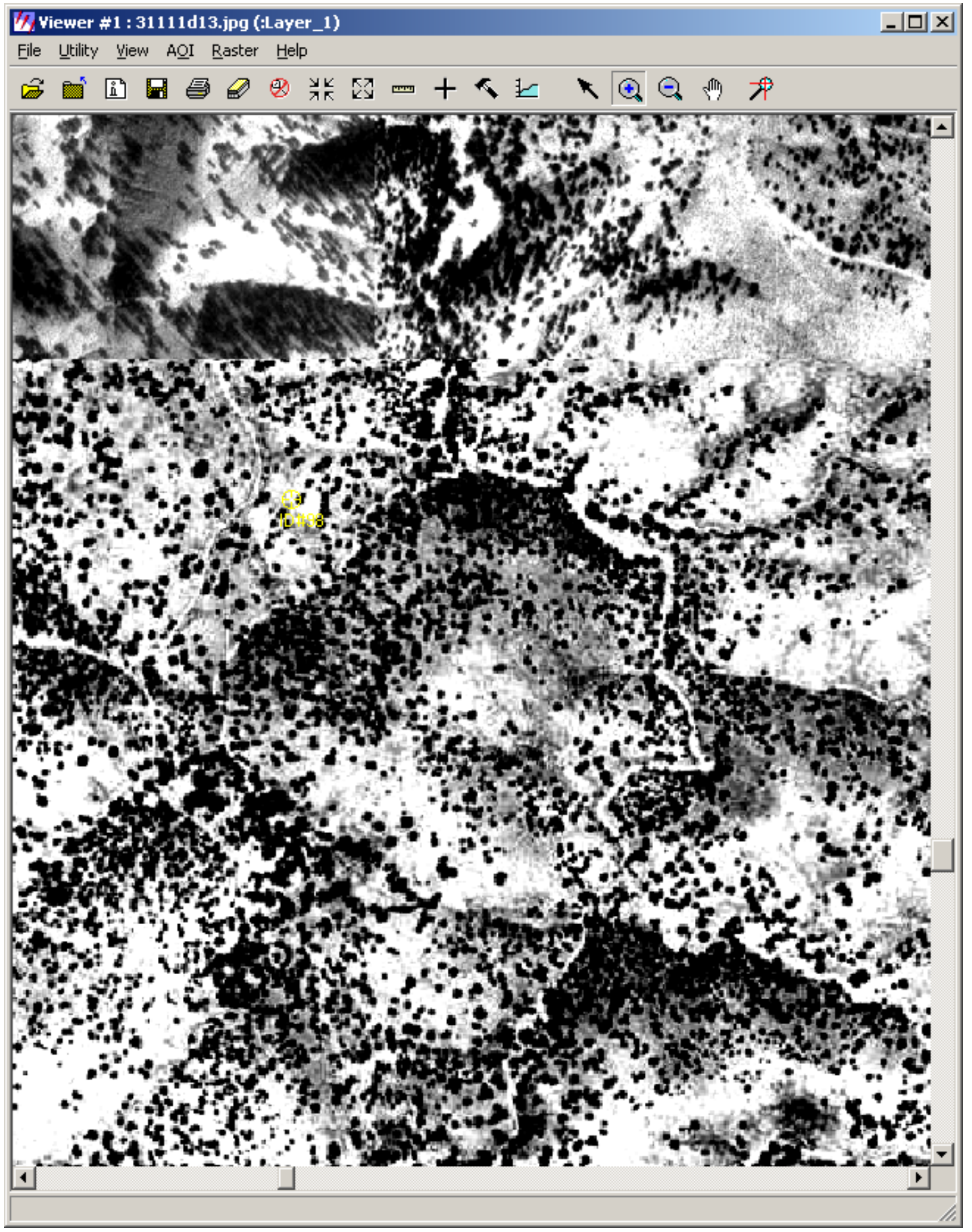

Figure 8: D000 of area south of the U.S.-Mexico border. 
Additionally, in Nogales, Sonora, a lot of area that is residential is classified as Bare (fig. 9) because the neighborhood design (bare soils, raw housing materials) varies from the design normally seen in the U.S. We left these Sonora residential areas classified as bare because it most accurately represents the terrain, especially since this map will be used as input to a hydrological model (not particularly created for urban planning purposes; fig. $10)$. 


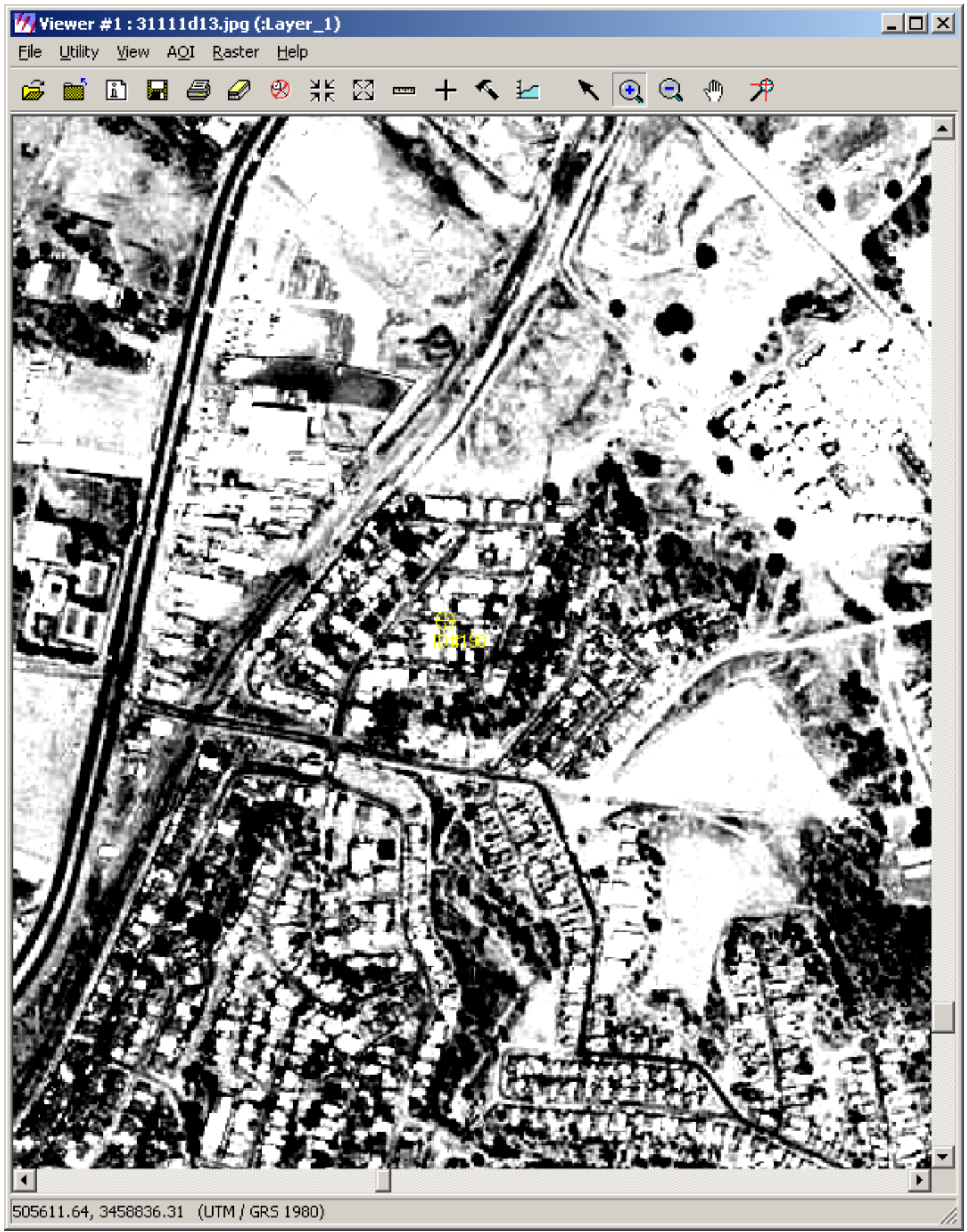

Figure 9. Residential area in Nogales, Sonora, that was classified as Bare

Rock/Sand/Clay. 


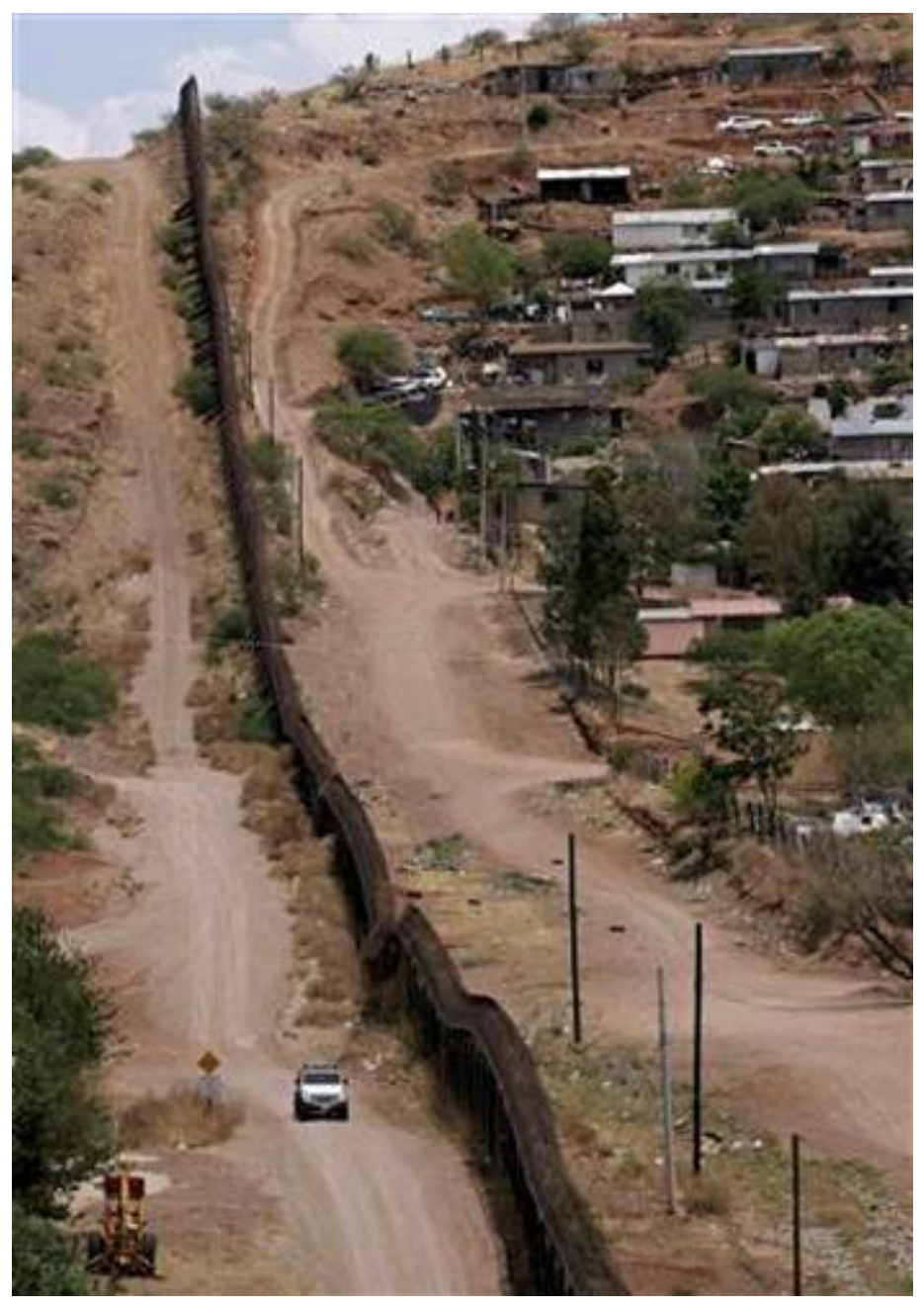

Figure 10: Picture of colonias at the U.S.-Mexico border in Ambos Nogales showing lack of pavement on roads in this watershed.

(http://www.worldproutassembly.org/archives/2006/12/children cross.html, last accessed December 21, 2008).

\section{Accuracy Assessment Report}

An error matrix was created to evaluate the new map’s accuracy, to compare the reference class values to the assigned class values, and to identify errors of inclusion (commission errors) and exclusion (omission errors) present in the map (Congalton and 
Green, 1999; table 1). A commission error occurs when an area is misclassified to an incorrect category. An omission error occurs when an area is excluded from the class to which it belongs. In addition to showing errors of omission and commission, the error matrix can be used to compute overall accuracy (table 2). Finally, the Kappa coefficient expresses the proportionate reduction in error generated by a classification process compared with the error of a completely random classification (table 3). 
Table 1. Error Matrix

\begin{tabular}{|c|c|c|c|c|c|c|c|c|c|}
\hline & $\begin{array}{l}\text { Commercial/ } \\
\text { Industrial/ } \\
\text { Transport }\end{array}$ & $\begin{array}{l}\text { Deciduous } \\
\text { Forest }\end{array}$ & $\begin{array}{l}\text { Grassland/ } \\
\text { Herbaceous }\end{array}$ & $\begin{array}{l}\text { Bare } \\
\text { Rock/ } \\
\text { Sand/ } \\
\text { Clay }\end{array}$ & $\begin{array}{l}\text { Quarries/ } \\
\text { Strip Mines/ } \\
\text { Gravel Pit }\end{array}$ & Shrubland & $\begin{array}{l}\text { Low } \\
\text { Intensity } \\
\text { Residential }\end{array}$ & $\begin{array}{l}\text { Urban/ } \\
\text { Recreational } \\
\text { Grasses }\end{array}$ & $\begin{array}{l}\text { Classified } \\
\text { total }\end{array}$ \\
\hline $\begin{array}{l}\text { Commercial/ Industrial/ } \\
\text { Transport }\end{array}$ & 46 & 0 & 0 & 1 & 0 & 3 & 0 & 0 & 50 \\
\hline Deciduous Forest & 0 & 46 & 1 & 0 & 0 & 3 & 0 & 0 & 50 \\
\hline Grassland/ Herbaceous & 0 & 0 & 33 & 0 & 0 & 17 & 0 & 0 & 50 \\
\hline Bare Rock/ Sand/ Clay & 1 & 1 & 0 & 47 & 0 & 1 & 0 & 0 & 50 \\
\hline $\begin{array}{l}\text { Quarries/ Strip Mines/ } \\
\text { Gravel Pit }\end{array}$ & 1 & 0 & 3 & 10 & 6 & 28 & 2 & 0 & 50 \\
\hline Shrubland & 1 & 1 & 0 & 0 & 0 & 48 & 0 & 0 & 50 \\
\hline Low Intensity Residential & 0 & 0 & 0 & 1 & 0 & 0 & 49 & 0 & 50 \\
\hline $\begin{array}{l}\text { Urban/ Recreational } \\
\text { Grasses }\end{array}$ & 0 & 2 & 18 & 2 & 0 & 21 & 1 & 6 & 50 \\
\hline Reference total & 49 & 50 & 55 & 61 & 6 & 121 & 52 & 6 & 400 \\
\hline
\end{tabular}


Table 2. Accuracy Totals.

\begin{tabular}{|c|c|c|c|c|c|}
\hline & $\begin{array}{l}\text { Reference } \\
\text { totals }\end{array}$ & $\begin{array}{l}\text { Classified } \\
\text { totals }\end{array}$ & $\begin{array}{c}\text { Number } \\
\text { correct }\end{array}$ & $\begin{array}{c}\text { Producers } \\
\text { accuracy, in } \\
\text { percent }\end{array}$ & $\begin{array}{c}\text { Users } \\
\text { accuracy, in } \\
\text { percent }\end{array}$ \\
\hline $\begin{array}{l}\text { Commercial/ } \\
\text { Industrial/ } \\
\text { Transport }\end{array}$ & 49 & 50 & 46 & 93.88 & 92 \\
\hline Deciduous Forest & 50 & 50 & 46 & 92.00 & 92 \\
\hline $\begin{array}{l}\text { Grassland/ } \\
\text { Herbaceous }\end{array}$ & 55 & 50 & 33 & 60.00 & 66 \\
\hline $\begin{array}{l}\text { Bare Rock/ Sand/ } \\
\text { Clay }\end{array}$ & 61 & 50 & 47 & 77.05 & 94 \\
\hline $\begin{array}{l}\text { Quarries/ Strip } \\
\text { Mines/ Gravel Pit }\end{array}$ & 6 & 50 & 6 & 100.00 & 12 \\
\hline Shrubland & 121 & 50 & 48 & 39.67 & 96 \\
\hline $\begin{array}{l}\text { Low Intensity } \\
\text { Residential }\end{array}$ & 52 & 50 & 49 & 94.23 & 98 \\
\hline $\begin{array}{l}\text { Urban/ } \\
\text { Recreational } \\
\text { Grasses }\end{array}$ & 6 & 50 & 6 & 100.00 & 12 \\
\hline Totals & 400 & 400 & 281 & & \\
\hline
\end{tabular}


Table 3. Conditional Kappa for each Category.

\begin{tabular}{l|c}
\hline \multicolumn{1}{c|}{ Class Name } & \multicolumn{1}{c}{ Kappa } \\
\hline Commercial/ Industrial/ Transport & 0.9088 \\
\hline Deciduous Forest & 0.9086 \\
\hline Grassland/ Herbaceous & 0.6058 \\
\hline Bare Rock/ Sand/ Clay & 0.9292 \\
\hline Quarries/ Strip Mines/ Gravel Pit & 0.1066 \\
\hline Shrubland & 0.9427 \\
\hline Low Intensity Residential & 0.9770 \\
\hline Urban/ Recreational Grasses & 0.1066 \\
\hline
\end{tabular}

The Overall Kappa $\left(\mathrm{K}^{\wedge}\right)$ Statistic was 0.66. This implies that the classification process is avoiding 66 percent of the errors that a completely random classification generates (Congalton, 2001). The overall classification accuracy was calculated to be 70.25 percent.

We were not satisfied with these results and so went back to the drawing board. The majority of error appeared to be with the Quarries/Strip Mine/Gravel Pit class and the Urban/Recreational Grasses class. The samples were merged into 6 signatures from the original 8 (1) Deciduous Forest, (2) Shrubland, (3) Low Intensity Residential, (4) Commercial/Industrial/Transport, (5) Combo Bare Rock/Quarries, and (6) Grasses (fig. $11)$. 


\begin{tabular}{|c|c|c|c|c|c|c|c|c|c|c|}
\hline \multicolumn{10}{|c|}{ QSignature Editor (classnlcddeadreckon_stu3.sig) } & \multirow[t]{2}{*}{$-|\square| x \mid$} \\
\hline File Edit & Vie & ew Evaluate Feature Classif & y Help & & & & & & & \\
\hline \multicolumn{11}{|c|}{$\left[\begin{array}{l}0 \\
0\end{array}\right.$} \\
\hline Class \# & $>$ & Siqnature Name & Color & Red & Green & Blue & Value & Order & Count & Prob. $1 \Delta$ \\
\hline 1 & \multicolumn{2}{|r|}{ Deciduous Forest } & & 0.000 & 0.392 & 0.000 & 4 & 40 & 188 & 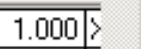 \\
\hline 2 & & Shrubland & & 0.824 & 0.706 & 0.549 & 9 & 60 & 14187 & $1.000 \mid>$ \\
\hline 3 & & Low Intesitry Residential & & 1.000 & 0.753 & 0.796 & 12 & 61 & 579 & $1.000 \mid>$ \\
\hline 4 & & Commercial//ndustrial/Transport & & 0.690 & 0.188 & 0.376 & 3 & 62 & 697 & $1.000 \mid>$ \\
\hline 5 & \multicolumn{2}{|r|}{ Combo_Bare Rock/Quarries } & & 0.827 & 0.827 & 0.827 & 1 & 63 & 168 & 1.000 \\
\hline & \multicolumn{2}{|r|}{ Grasses } & & 1.000 & 1.000 & 0.878 & 2 & 64 & 151 & $1.000 \mid>$ \\
\hline
\end{tabular}

Figure 11. Screengrab of ERDAS IMAGINE Signature Editor with 6 classes.

In the modified Anderson Level I binational classification scheme, the Anderson Level I rangeland class is sometimes split into two classes: shrubland and grassland/pasture. We considered further combining classes to merge grasslands and shrubs, but felt that given the hydrological modeling application, it would be more accurate to keep 2 separate classes.

We applied a supervised classification using these 6 signatures and the minimum distance rule to acquire a second pass cross-border land-cover map. Accuracy statistics were computed for the new map (Tables 4-6). 
Table 4. Error Matrix

\begin{tabular}{|c|c|c|c|c|c|c|c|}
\hline & $\begin{array}{l}\text { Commercial/ } \\
\text { Industrial/ } \\
\text { Transport }\end{array}$ & $\begin{array}{l}\text { Deciduous } \\
\text { Forest }\end{array}$ & Shrubland & $\begin{array}{l}\text { Low Intensity } \\
\text { Residential }\end{array}$ & $\begin{array}{l}\text { Combination } \\
\text { Grasses }\end{array}$ & $\begin{array}{l}\text { Combination } \\
\text { Bare }\end{array}$ & $\begin{array}{l}\text { Classified } \\
\text { Total }\end{array}$ \\
\hline $\begin{array}{l}\text { Commercial/ } \\
\text { Industrial/ Transport }\end{array}$ & 46 & 0 & 3 & 0 & 0 & 1 & 50 \\
\hline Deciduous Forest & 0 & 46 & 3 & 0 & 1 & 0 & 50 \\
\hline Shrubland & 1 & 1 & 48 & 0 & 0 & 0 & 50 \\
\hline $\begin{array}{l}\text { Low Intensity } \\
\text { Residential }\end{array}$ & 0 & 0 & 0 & 49 & 0 & 1 & 50 \\
\hline Combination Grasses & 0 & 2 & 38 & 1 & 57 & 2 & 100 \\
\hline Combination Bare & 2 & 1 & 29 & 2 & 3 & 63 & 100 \\
\hline Reference Total & 49 & 50 & 121 & 52 & 61 & 67 & 400 \\
\hline
\end{tabular}


Table 5. Accuracy Totals.

\begin{tabular}{|c|c|c|c|c|c|}
\hline & $\begin{array}{l}\text { Reference } \\
\text { totals }\end{array}$ & $\begin{array}{l}\text { Classified } \\
\text { totals }\end{array}$ & $\begin{array}{l}\text { Number } \\
\text { correct }\end{array}$ & $\begin{array}{l}\text { Producers } \\
\text { accuracy, in } \\
\text { percent }\end{array}$ & $\begin{array}{l}\text { Users } \\
\text { accuracy, } \\
\text { in percent }\end{array}$ \\
\hline Commercial/ Industrial/ Transport & 49 & 50 & 46 & 93.88 & \\
\hline Deciduous Forest & 50 & 50 & 46 & 92.00 & 92 \\
\hline Shrubland & 121 & 50 & 48 & 39.67 & 92 \\
\hline Low Intensity Residential & 52 & 50 & 49 & 94.23 & 96 \\
\hline Combination Grasses & 61 & 100 & 57 & 93.44 & 98 \\
\hline Combination Bare & 67 & 100 & 63 & 94.03 & 57 \\
\hline Totals & 400 & 400 & 309 & & \\
\hline
\end{tabular}


Table 6. Errors of omission, commission, and percent correct.

\begin{tabular}{|l|r|r|r|}
\hline & $\begin{array}{l}\text { Errors of } \\
\text { omission, in } \\
\text { percent }\end{array}$ & $\begin{array}{l}\text { Errors of } \\
\text { lommission, in } \\
\text { percent }\end{array}$ & Percent correct \\
\hline $\begin{array}{l}\text { Commercial/ Industrial/ } \\
\text { Transport }\end{array}$ & 6.12 & 8.16 & 93.88 \\
\hline Deciduous Forest & 8.00 & 8.00 & 92.00 \\
\hline Shrubland & 60.33 & 1.65 & 39.67 \\
\hline $\begin{array}{l}\text { Low Intensity } \\
\text { Residential }\end{array}$ & 6.77 & 1.92 & 94.23 \\
\hline Combination Grasses & 5.97 & 70.49 & 93.44 \\
\hline Combination Bare & $\mathbf{2 2 . 7 5}$ & 55.22 & $\mathbf{7 7 . 2 5}$ \\
\hline \multicolumn{1}{|c|}{ Totals } & & 22.75 & 94.03 \\
\hline
\end{tabular}

The Overall Kappa $\left(\mathrm{K}^{\wedge}\right)$ Statistic was 0.7275 - the classification process is avoiding 72.75 percent of the errors that a completely random classification generates and the overall classification accuracy was calculated to be 77.25 percent. The Ambos Nogales area is dominated by both shrubland and grassland around bare areas of transportation and urban sprawl (figs. 12 and 13), which is now represented in our new map. 


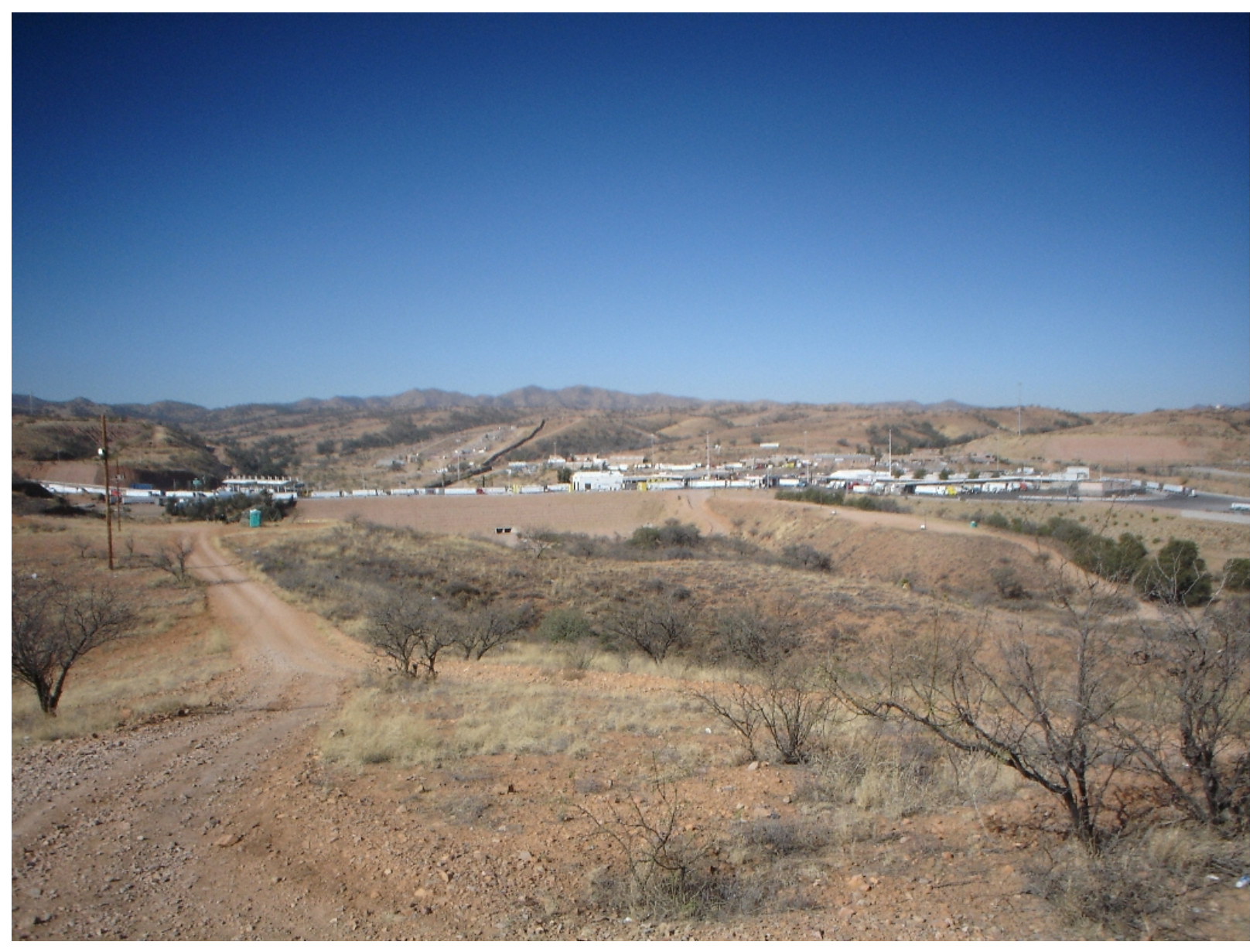

Figure 12. Image of property at the U.S.-Mexico border between Marisposa Rd. and I-19 in Nogales, Arizona (http://www.loopnet.com/Arizona/Nogales-commercial-realestate/?LinkCode=18400, last accessed June 21, 2008). 


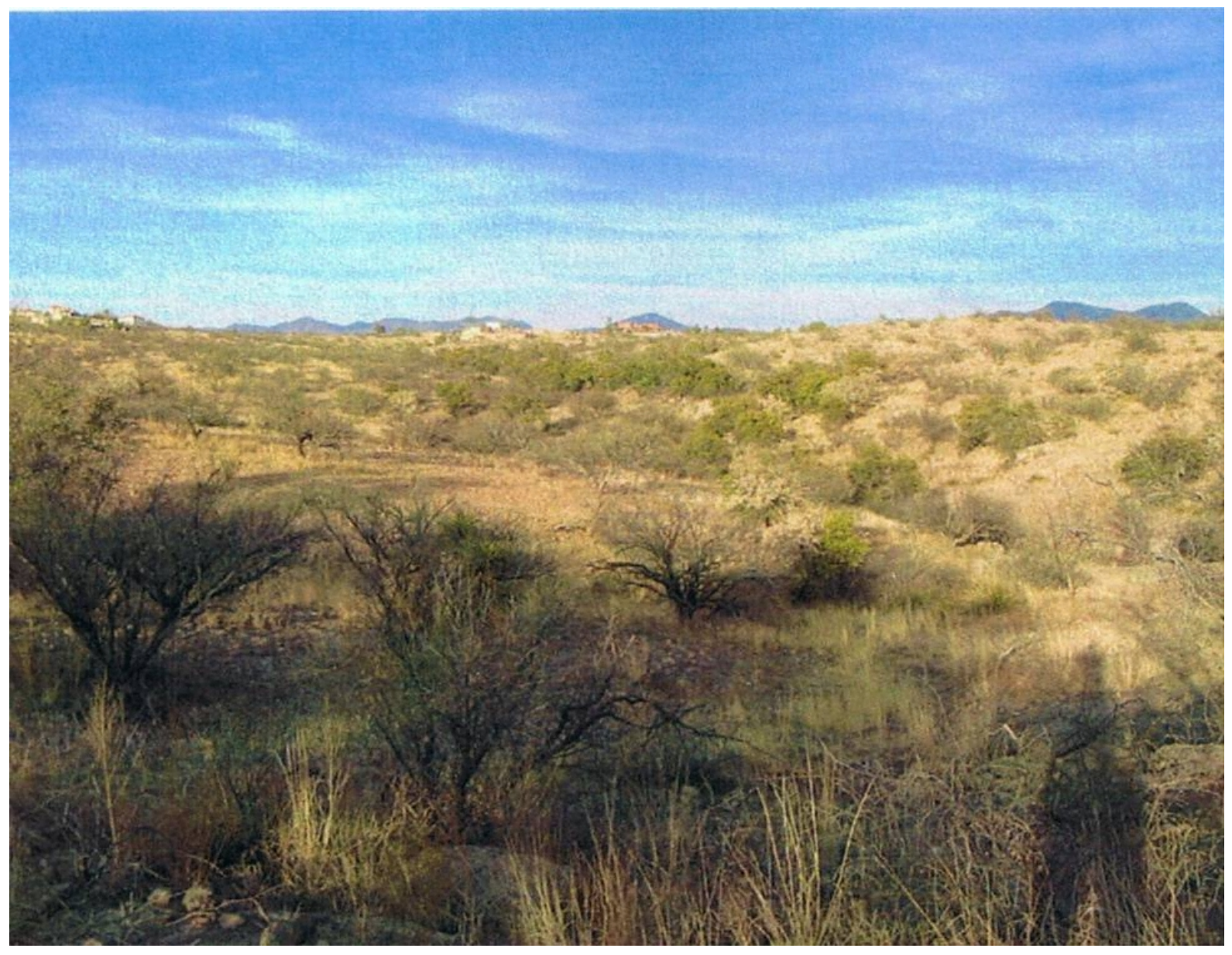

Figure 13. Photo of development land taken near Highway 82 in Nogales, Arizona

(http://www.loopnet.com/Arizona/Nogales-commercial-real-estate/?LinkCode=18400, last accessed June 21, 2008).

In order to make the dataset acceptable as input to AGWA2, some further manipulation of the dataset was necessary. AGWA2 accepts NLCD datasets as input using a look-up table for the MRLC (fig. 14). 


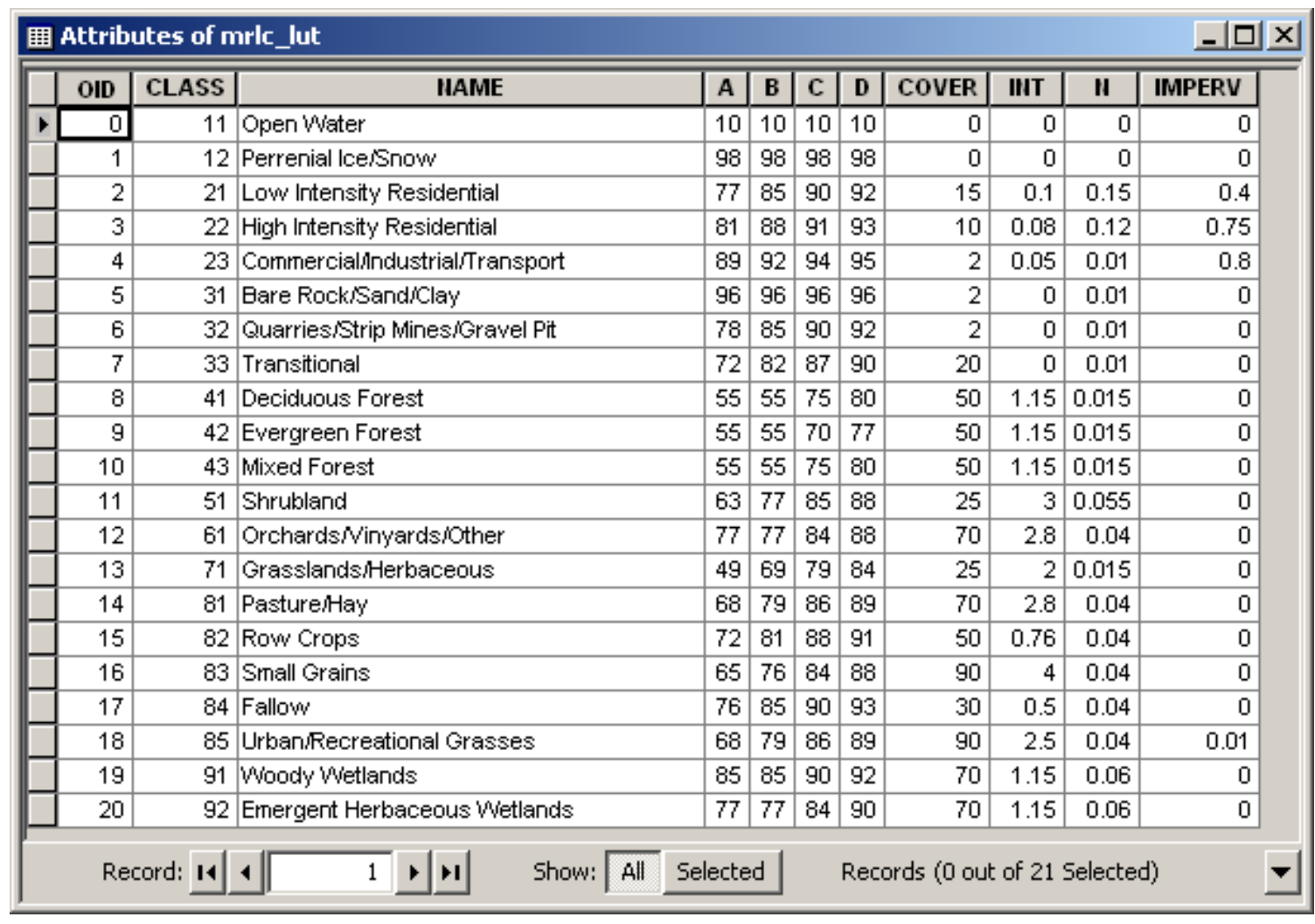

Figure 14. MRLC look-up table available in AGWA2.

Classes in the new image were assigned class numbers according to this table (fig. 15).

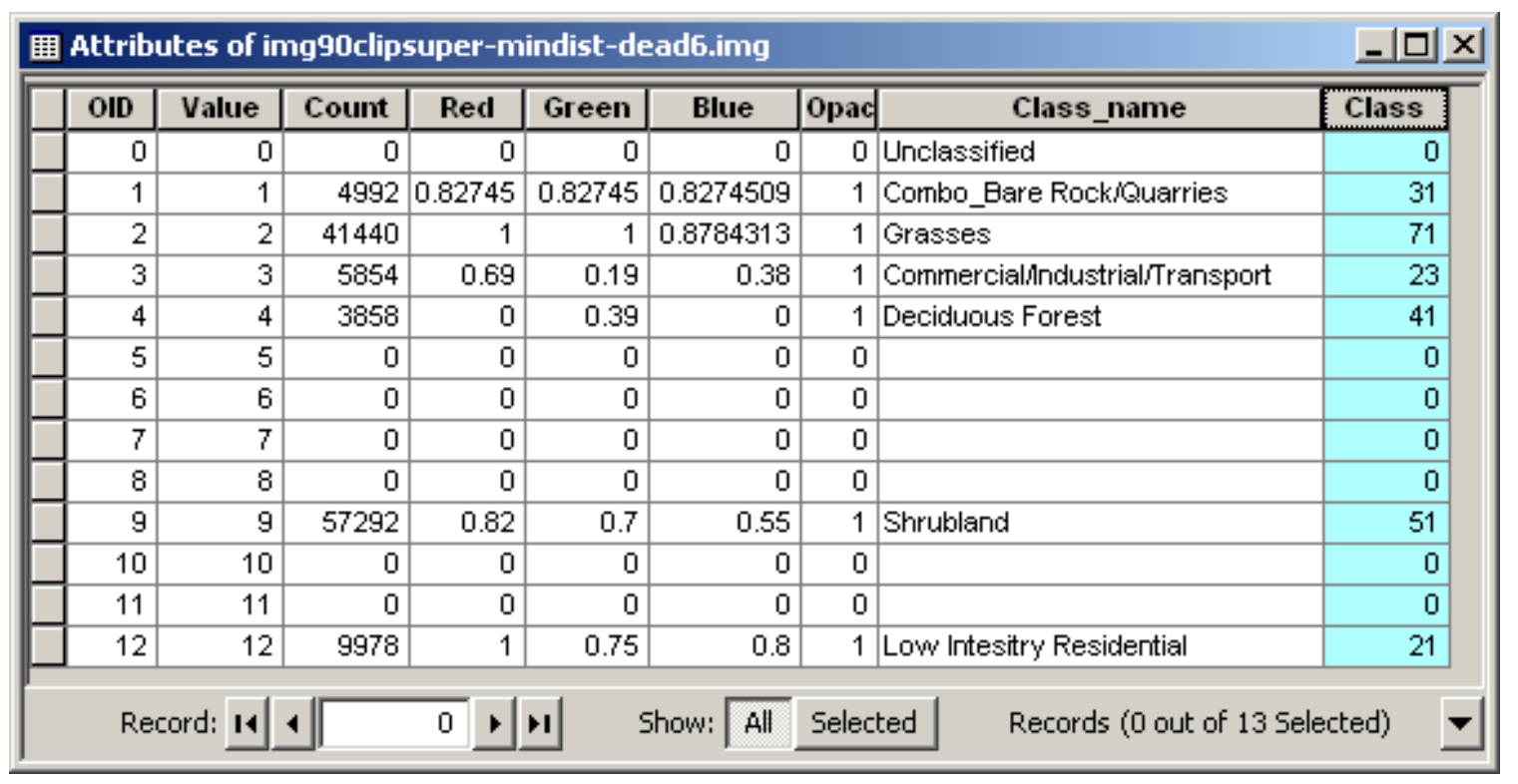

Figure 15. New "Class" attribute assigned to binational map. 
The image was converted to GRID format, to polygon format, and back to GRID format, to replace the Value field with the new CLASS numbers. The new GRID, "mrlc_Nogales" is appropriate for use in the AGWA model (figs. 16 and 17).

\begin{tabular}{|c|c|c|c|c|c|c|c|}
\hline \multicolumn{5}{|c|}{ 䡒 Attributes of MRLC_Nogales } & \multicolumn{3}{|c|}{$-\square \mid x$} \\
\hline & VALUE * & & owid & COUIIT & CLAS & & \\
\hline \multirow[t]{7}{*}{$\bullet$} & 1 & & 0 & 4992 & & 31 & \\
\hline & 2 & & 1 & 41440 & & 71 & \\
\hline & 3 & & 2 & 5854 & & 23 & \\
\hline & 4 & & 3 & 3858 & & 41 & \\
\hline & 9 & & 4 & 57292 & & 51 & \\
\hline & 12 & & 5 & 9978 & & 21 & \\
\hline & Record: & 14 & 1 & 1 & $\bullet$ & Show: & $\boldsymbol{\nabla}$ \\
\hline
\end{tabular}

Figure 16. Final attribute table for the raster binational land-cover input of Ambos Nogales, Arizona, United States, and Sonora, Mexico. 


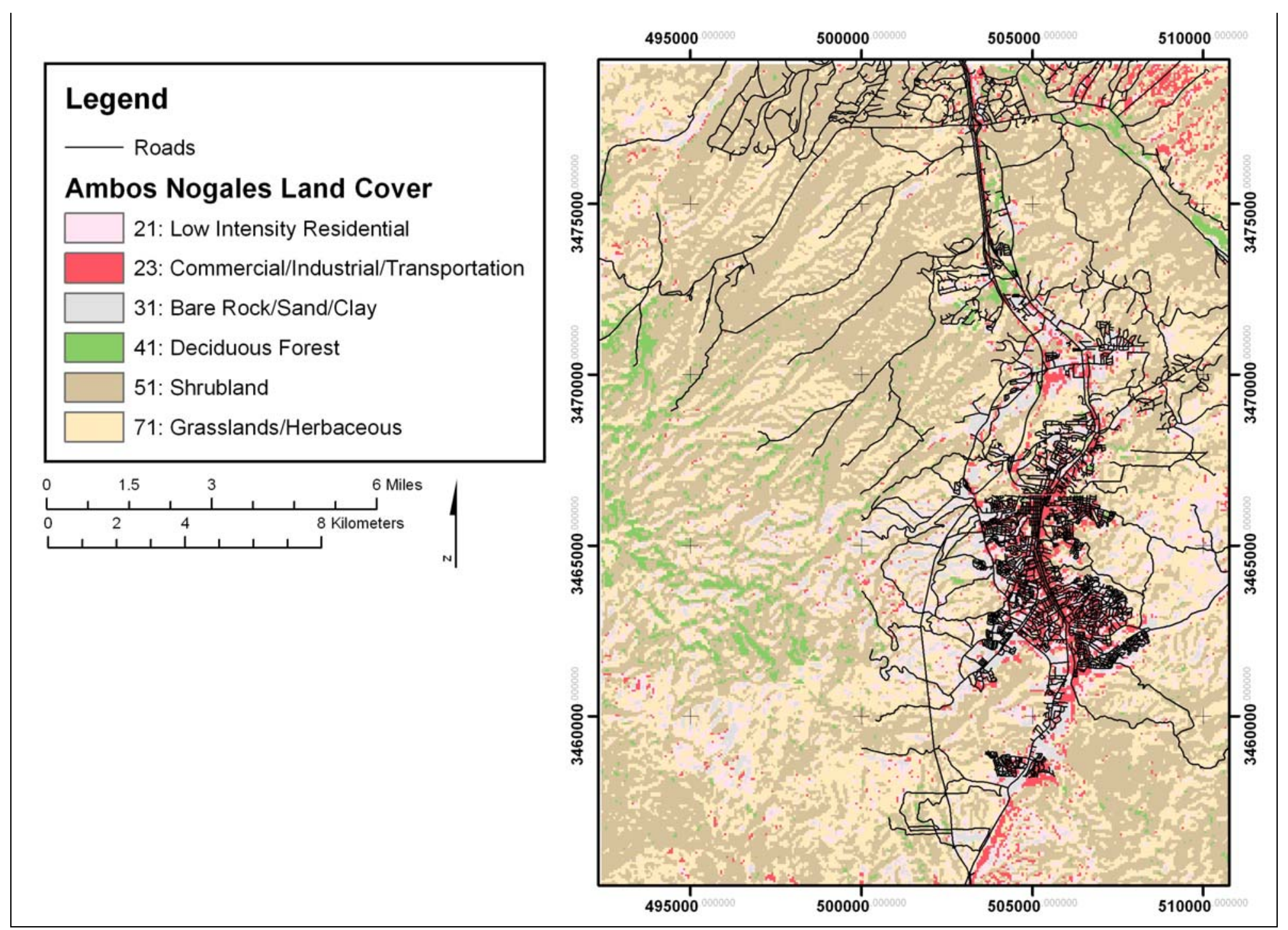

Figure 17. Final binational land-cover map of Ambos Nogales, Arizona, United States, and Sonora, Mexico, for input to AGWA2. 


\section{Conclusions}

Environmental modeling across international borders can be challenging due to differences in language, nomenclature, scale, style, and priorities. Remotely sensed images can be used to create seamless data across administrative boundaries for input into models. This research paper describes procedures used to create a binational land use/land-cover map of use in the AGWA KINEROS2 model.

\section{Acknowledgments}

The authors would like to thank Darius Semmens and Lainie Levick for their reviews of this report; also Theresa Mathiasmeier for her review of the metadata. 


\section{REFERENCES}

Anderson, J.R., Hardy, E.E., Roach, J.T. and Witmer, R.E., 1976, A land use and land cover classification system for use with remote sensor data: U.S. Geological Survey Professional Paper 964. [http://landcover.usgs.gov/pdf/anderson.pdf, last accessed December 21, 2008].

Congalton, R., 2001, Accuracy assessment and validation of remotely sensed and other spatial information: The International Journal of Wildland Fire. V. 10. p. 321-328.

Congalton, R. and Green, K., 1999, Assessing the accuracy of remotely sensed dataPrinciples and practices: Boca Raton, Fla., CRC/Lewis Press, 137 p.

Gaydos, L., 1996, Today’s land cover mapping, in Scott, J.M., Tear, T.H., and Davis, F., eds., Gap analysis-A landscape approach to biodiversity planning: Bethesda, Md., American Society for Photogrammetry and Remote Sensing, p. 67-70.

Instituto Nacional de Estadística, Informática e Geografía (INEGI), 1993, Guía Para la Interpretación de Información Cartográfica Impresa y Digital de Uso de Suelo.

Loveland T.R., and Shaw, D.M., 1996, MultiResolution land characterization-Building collaborative partnershipsi, in Scott, J.M., Tear, T.H., and Davis, F., eds., Gap analysisA landscape approach to biodiversity planning, Proceedings of the ASPRS/GAP Symposium: Charlotte, N.C., National Biological Service, Moscow, ID, p. 83-89.

Lunetta, R.S., and Sturdevant, J.A., 1993, The North American landscape characterization Landsat Pathfinder project, in Pettinger, L.R., ed., Pecora 12 symposium, land information from space-based systems, Proceedings: Bethesda, Md., American Society of Photogrammetry and Remote Sensing, p. 363-371.

Miller, S.N., Semmens, D.J., Miller, R.C., Hernandez, M., Miller, W.P., Goodrich, D.C., Kepner, W.G., and Ebert, D., 2002, GIS-based hydrologic modeling-The automated geospatial watershed assessment tool, Proceedings 2nd Federal Interagency Conf. on Hydrologic, July 29-Aug. 1, Las Vegas, Nev.

Parcher, J.W., Norman, L.M., Papoulias, D.M., Stefanov, J.E., Wilson, Z.D., Page, W.R., and Gary, R.H., 2006, Developing a binational geodatabase to examine environmental health and quality-of-life issues along the U.S.-Mexico border: GSDI-9 Conference Proceedings, 6-10 November, Santiago, Chile. 
Semmens, D.J., Goodrich, D.C., Unkrich, C.L., Smith, R.E., Woolhiser, D.A. and Miller, S.N., 2008, KINEROS2 and the AGWA modeling framework, in Wheater, H., Sorooshian, S., and Sharma, K.D., eds., Hydrological Modelling In Arid and SemiArid Areas, New York, Cambridge University Press, 206 p.

U.S. Geological Survey, 2000, National land cover dataset: U.S. Geological Survey Fact Sheet 108-00 [http://erg.usgs.gov/isb/pubs/factsheets/fs10800.html, last accessed

December 21, 2008].

Vogelmann, J.E., Howard, S.M., Yang, L., Larson, C.R., Wylie, B.K., and Van Driel, J.N., 2001, Completion of the 1990's National Land Cover Data Set for the conterminous United States, Photogrammetric Engineering and Remote Sensing v. 67, p. 650-662.

Wilson, Z.D., 2006, Binational integration of national land use/land cover datasets in the United States-Mexico border region

[http://borderhealth.cr.usgs.gov/PDFs/website_methods_LandCoverIntegration_2006063 0.pdf, last accessed December 21, 2008].

Woolhiser, D.A., Hanson, C.L., and Kuhlman, A.R., 1970, Overland flow on rangeland watersheds: Journal of Hydrology, v. 9, no. 2, p. 336-335. 


\title{
Appendix A-Metadata
}

\author{
Identification_Information: \\ Citation: \\ Citation_Information: \\ Originator: Laura Norman and Cynthia Wallace \\ Publication_Date: Unknown \\ Title: Land Use/Land Cover in the Ambos Nogales Watershed; Nogales, Arizona, \\ United States and Nogales, Sonora, Mexico \\ Geospatial_Data_Presentation_Form: raster digital data \\ Online_Linkage: TBD \\ Larger_Work_Citation: \\ Citation_Information: \\ Originator: Laura Norman and Cynthia Wallace \\ Publication_Date: Unknown \\ Title: Mapping Land Use/Land Cover in the Ambos Nogales Study Area \\ Geospatial_Data_Presentation_Form: raster digital data \\ Series_Information: \\ Series_Name: Open File Report \\ Publication_Information: \\ Publisher: U.S. Geological Survey \\ Description:
}

Abstract: An integer GRID dataset representing the distribution of landscape classes across the Ambos Nogales Watershed was created. Six signatures that correlate with the Multi-Resolution Land Characteristics (MRLC) Consortium classes were identified using image processing techniques in ERDAS IMAGINE 9.1 software to develop a binational land cover dataset similar to the National Land Cover Dataset (NLCD). Data resolution is $60 \mathrm{~m}$., based on the source Landsat MSS imagery in 1992.

Purpose: This dataset was created to be used as input to the Automated Geospatial Watershed Assessment (AGWA) Tool, in order to predict runoff in this urbanizing watershed.

Time_Period_of_Content:

Time_Period_Information:

Single_Date/Time:

Calendar_Date: 10/07/92

Currentness_Reference: ground condition

Status:

Progress: Complete

Maintenance_and_Update_Frequency: None planned

Spatial_Domain:

Bounding_Coordinates:

West_Bounding_Coordinate: -111.080090

East_Bounding_Coordinate: -110.886233

North_Bounding_Coordinate: 31.446346

South_Bounding_Coordinate: 31.228667

Keywords: 
Theme:

Theme_Keyword: Land use

Theme_Keyword: Land Cover

Place:

Place_Keyword: Nogales

Place_Keyword: Sonora

Place_Keyword: Arizona

Place_Keyword: Mexico

Access_Constraints: None.

Use_Constraints: There is no guarantee concerning the accuracy of the data. Users

should be aware that temporal changes may have occurred since this data set was collected and that some parts of this data may no longer represent actual surface conditions. Users should not use this data for critical applications without a full awareness of its limitations. Acknowledgement of the originating agencies would be appreciated in products derived from these data. Any user who modifies the data is obligated to describe the types of modifications they perform. User specifically agrees not to misrepresent the data, nor to imply that changes made were approved or endorsed by the U.S. Geological Survey. Please refer to <http://www.usgs.gov/privacy.html $>$ for the USGS disclaimer.

Point_of_Contact:

Contact_Information:

Contact_Person_Primary:

Contact_Person: Laura Norman

Contact_Organization: US Geological Survey

Contact_Position: Research Scientist

Contact_Address:

Address_Type: mailing and physical address

Address: 520 N. Park Ave., Ste \#355

City: Tucson

State_or_Province: AZ

Postal_Code: 85719

Country: USA

Contact_Voice_Telephone: 5206705510

Contact_Electronic_Mail_Address: lnorman@usgs.gov

Native_Data_Set_Environment: Microsoft Windows XP Version 5.1 (Build 2600)

Service Pack 2; ESRI ArcCatalog 9.2.2.1350

Data_Quality_Information:

Attribute_Accuracy:

Attribute_Accuracy_Report: The Overall Kappa $\left(\mathrm{K}^{\wedge}\right)$ Statistics was 0.7275-the classification process is avoiding 72.75 percent of the errors that a completely random classification generates and the overall classification accuracy was calculated to be $77.25 \%$. The area is dominated by both shrubland and grassland around bare areas of transportation and urban sprawl, which is now represented in our map.

Logical_Consistency_Report: The accuracy of the dataset is based on the software's ability to detect land use signatures and the analysts's interpretation of features on the groud. Additional inaccuracy could occur in the original image it was processed from, 
because even slight measurement inaccuracies of the ground features selected for ortho control can affect the final accuracy.

Completeness_Report: Data are limited to areas included in the Ambos Nogales study area as defined by a minimum bounding rectangle around the watershed.

Lineage:

Source_Information:

Source_Citation:

Citation_Information:

Originator: National Aeronautics and Space Administration (NASA) Landsat

Pathfinder Program

Publication_Date: Unknown

Title: North American Landscape Characterization

Online_Linkage: http://GloVis.usgs.gov/

Type_of_Source_Media: remote sensing image

Source_Time_Period_of_Content:

Time_Period_Information:

Single_Date/Time:

Calendar_Date: 19921007

Source_Citation_Abbreviation: NALC dataset from 10/07.1992 for Path 26, Row 38.

Source_Contribution: North American Landscape Characterization (NALC) data are

Landsat Multi-Spectral Scanner (MSS) time-series triplicates that were acquired in 1973, 1986, and 1991 (+/- one year). Pixel size for all images is 60 meters. The data has been cast to the Universal Transverse Mercator (UTM) projection and is referenced to the North American Datum of 1927 (NAD27).

Process_Step:

Process_Description: Applied supervised classification, using signatures calculated from the NLCD of Nogales, Ariz., using the minimum distance rule, to acquire cross border signatures.

Process_Date: 20080501

Process_Step:

Process_Description: Created a CellArray that listed two sets of class values for 400 randomly selected points in the classified .img file. One set of class values was automatically assigned to these random points as they are selected (hidden in figure below-in order to get unbiased reference samples), and the other set of class values (reference values) was input .

Process_Date: 20080501

Process_Step:

Process_Description: Checked accuracy of classification using DOQQs and created accuracy report. We were not satisfied with these results and so we merged signatures. We applied a supervised classification using these 6 signatures and the minimum distance rule, to acquire a more accurate cross-border land cover map

Process_Date: 20080501

Spatial_Data_Organization_Information:

Direct_Spatial_Reference_Method: Raster

Raster_Object_Information:

Raster_Object_Type: Grid Cell 
Row_Count: 402

Column_Count: 307

Vertical_Count: 1

Spatial_Reference_Information:

Horizontal_Coordinate_System_Definition:

Planar:

Grid_Coordinate_System:

Grid_Coordinate_System_Name: Universal Transverse Mercator

Universal_Transverse_Mercator:

UTM_Zone_Number: 12

Transverse_Mercator:

Scale_Factor_at_Central_Meridian: 0.999600

Longitude_of_Central_Meridian: -111.000000

Latitude_of_Projection_Origin: 0.000000

False_Easting: 500000.000000

False_Northing: 0.000000

Planar_Coordinate_Information:

Planar_Coordinate_Encoding_Method: row and column

Coordinate_Representation:

Abscissa_Resolution: 60.000000

Ordinate_Resolution: 60.000000

Planar_Distance_Units: meters

Geodetic_Model:

Horizontal_Datum_Name: North American Datum of 1983

Ellipsoid_Name: Geodetic Reference System 80

Semi-major_Axis: 6378137.000000

Denominator_of_Flattening_Ratio: 298.257222

Entity_and_Attribute_Information:

Detailed_Description:

Entity_Type:

Entity_Type_Label: mrlc_nogales.vat

Entity_Type_Definition: Land use classes

Entity_Type_Definition_Source: Multi-Resolution Land Cover Characterization (MRLC)

Attribute:

Attribute_Label: Rowid

Attribute_Definition: Internal feature number.

Attribute_Definition_Source: ESRI

Attribute_Domain_Values:

Unrepresentable_Domain: Sequential unique whole numbers that are automatically generated.

Attribute:

Attribute_Label: VALUE

Attribute_Definition: Internal ID \# from image processing steps.

Attribute:

Attribute_Label: COUNT 
Attribute_Definition: Number of GRID cells assigned to this value.

Attribute:

Attribute_Label: CLASS

Attribute_Definition: Class created to correspond with the NLCD data.

Attribute_Definition_Source: Multi-Resolution Land Cover Characterization (MRLC)

Distribution_Information:

Distributor:

Contact_Information:

Contact_Person_Primary:

Contact_Person: Laura M. Norman

Contact_Organization: U.S. Geological Survey

Contact_Address:

Address_Type: mailing and physical address

Address: 520 N. Park Ave., Ste \#104

City: Tucson

State_or_Province: AZ

Postal_Code: 85719

Country: USA

Contact_Electronic_Mail_Address: lnorman@usgs.gov

Resource_Description: Downloadable Data

Standard_Order_Process:

Digital_Form:

Digital_Transfer_Information:

Format_Name: GRID

Transfer_Size: 0.091

Ordering_Instructions: Data are available online at no charge via Internet download.

Acknowledgement of the U.S. Geological Survey would be appreciated in products

derived from these data

Metadata_Reference_Information:

Metadata_Date: 20080903

Metadata_Contact:

Contact_Information:

Contact_Person_Primary:

Contact_Person: Laura M. Norman

Contact_Organization: US Geological Survey

Contact_Address:

Address_Type: mailing and physical address

Address: 520 N. Park Ave, Ste \#355

City: Tucson

State_or_Province: AZ

Postal_Code: 85719

Contact_Voice_Telephone: 5206705510

Metadata_Standard_Name: FGDC Content Standards for Digital Geospatial Metadata

Metadata_Standard_Version: FGDC-STD-001-1998

Metadata_Time_Convention: local time

Metadata_Extensions: 
Profile_Name: ESRI Metadata Profile

Metadata_Extensions:

Online_Linkage: http://www.esri.com/metadata/esriprof80.html

Profile_Name: ESRI Metadata Profile 